deficiency in the health services. Questions related to the universe of the guarantee of rights. Historically, the handicap people had been kept out of society in the society and the public politics were come back toward the institutional segregation. After that the integration model was adopted and currently the inclusion concept is most recent and represents an attempt of advance how much to the question in what it refers to the construction of an accessible society for all, people with or without deficiency. To think about marginalizao in also sends them to the debate on the poverty in the health system since in the whole world, according to studies and research, the people with deficiency are between the poor of the poor persons, living lives of disadvantage and privation, living under the stigma of the double discrimination: of being handicap person and of being poor.

\section{REFLECTIONS ON ATTENDANCE THE FAMILIES OF HANDICAP PEOPLE: LIMITS AND POSSIBILITIES IN THE INTERVENTION OF THE SOCIAL WORK}

T M Arajo da Fonseca, T M Campos de Azevedo, L Ximenes* Correspondence: Universidade Federal Fluminense, Rua Senador Jos Guiomard, 5, Parque So Pedro, Campo Grande, RJ, 23093-160, Brazil

\subsection{6/ip.2010.029215.145}

The familiar nucleus gained new contours in the process of social changes throughout the last years. The families arrive at the public services, with prominence in the services of health and patriarcais, extensive models, recompostas, monoparental, among others. Independent of its configuration, the family continues being the social institution that represents the first and important canal of initiation of the affection, the socialisation, the relations of learning and cares in health. It has that to understand the especificidades of the familiar dynamics of the nuclei that possess one of its members with 